\title{
PRAWA I SPRAWIEDLIWOŚCI KRYTYKA KONSTYTUCJI RZECZYPOSPOLITEJ POLSKIEJ Z 1997 R.
}

\author{
LAW AND JUSTICE'S CRITICISM OF THE CONSTITUTION \\ OF THE REPUBLIC OF POLAND OF 1997
}

\begin{abstract}
The article refers to the position of the Law and Justice party as regards the Polish fundamental law, in force since 1997. Diagnosing the constitution, Law and Justice politicians pointed to its flaws and provisions resulting in the systemic weakness of the state. The diagnosis comprised four problematic areas: circumstances (origin) of the passing of the Constitution of 1997, criticism of axiological foundations and systemic regulations, as well as legal systemic effects of constitutional provisions. Questioning a relevant part of Poland's systemic achievements after 1989, Law and Justice saw the need for fundamental changes in almost all spheres of political and social life. The party's answer to the multi-sphere state crisis was the project of the Fourth Republic of Poland, signifying a radical reconstruction of the state. The basis for the proposed changes was to be the new constitution. Law and Justice's idea of "the good constitution" expressed the will to found a strong, independent state, which would "play the role of a depositary of values and historic heritage". The party's views on the Constitution of the Third Republic of Poland were in line with the broader project of building a strong state. There dominated the view that "democratic" or "liberal" values cannot serve to specify the ideological foundations of social and political order. The priority was to clearly define the anticommunist identity and to found modernization of the state on tradition.
\end{abstract}

Słowa kluczowe: konstytucja, myśl polityczna, Prawo i Sprawiedliwość, ustrój państwa

Key words: Constitution, political thought, Law and Justice, system of the state

* Dr Joanna Sanecka-Tyczyńska, Uniwersytet Marii Curie-Skłodowskiej w Lublinie, Wydział Politologii; joannasanecka@o2.pl

\section{UWAGI WSTĘPNE}

W demokratycznych państwach konstytucja pełni rolę najwyższego prawa. Określa ramy ustrojowe politycznej organizacji społeczeństwa jako spoiwo utrzymujące je w całości. Kodyfikuje normy prawne, definiuje ład aksjologiczny i określa tożsamość wspólnoty politycznej ${ }^{1}$. Pożądaną wartością w odniesieniu do ustawy zasadniczej jest jej stabilność, co nie może oznaczać niezmienności. Konstytucja, aby móc dobrze pełnić przypisane jej funkcje, powinna być modyfikowana, aby odpowiadać na wyzwania zmieniającej się rzeczywistości.

Należy się zgodzić z Josephem Weilerem, że ustawa zasadnicza, oprócz określenia organizacji władz państwa i podziału kompetencji między instytucjami oraz ustalenia i normalizacji stosunków między obywatelami a władzą publiczną, ,jest także pewnego rodzaju depozytem, który odzwierciedla i chroni wartości, ideały i symbole

${ }^{1}$ A. Hamlin, Constitutions, Politics and Identity, [w:] Constitutional Mythologies. New Perspectives on Controlling the State, red. A. Marciano, Nowy Jork 2011, s. 49. 
podzielane przez społeczność. Jest więc odbiciem tej społeczności, istotnym elementem jej samoświadomości, odgrywającym podstawową rolę w definiowaniu tożsamości narodowej, kulturalnej i aksjologicznej narodu, który ją przyjął. [...] Podstawowe prawa to system wartości, nośnik określonych wyborów etycznych, stanowią zatem selektywne i normatywne kryterium określające prawomocność"2.

W 2017 r. minęło 20 lat od wejścia w życie Konstytucji RP. Polska ustawa zasadnicza w czasie swojego obowiązywania była modyfikowana zaledwie dwa razy ${ }^{3}$. Nie oznaczało to bynajmniej braku sporów politycznych ogniskujących się wokół jej oceny. Partia Prawo i Sprawiedliwość od początku swojego powstania w 2001 r. opowiadała się za zmianą ustawy zasadniczej.

Artykuł odnosi się do stanowiska partii Prawo i Sprawiedliwość wobec obowiązującej od 1997 r. polskiej konstytucji. Podzielony jest on na dwie części odnoszące się do myśli politycznej PiS: pierwsza zawiera ocenę rozwiązań konstytucyjnych, druga - warunki i zasady uchwalenia „dobrej” konstytucji. Celem badawczym autorki artykułu jest odpowiedź na kilka pytań: Jak politycy PiS oceniali przepisy konstytucyjne z 1997 r.? Jakie cechy powinna mieć „dobra konstytucja”? Jakie funkcje jej przypisywano? Na jakich wartościach i zasadach ustrojowych chciano oprzeć przyszłą konstytucję?

\section{OCENA KONSTYTUCJI RP Z 1997 R.}

W myśli politycznej PiS konstytucja jako akt prawny najwyższego rzędu była traktowana z szacunkiem, lecz bez dogmatyzmu i bezwarunkowego tolerowania jej słabości. Reformę konstytucji uważano za przejaw dojrzałości państwa demokratycznego. Dominowało przeświadczenie, że konstytucja nie jest „cudownym lekarstwem” na wszystkie problemy polityczne i społeczne, niemniej jednak może wspomagać rozwój państwa albo go blokować. Ideę dobrej konstytucji łączono z wolą budowy silnego państwa ${ }^{4}$.

W myśli politycznej PiS konstytucja była nie tylko filarem ustrojowym (zbiór przepisów prawnych), ale i moralnym (zbiór zasad i wartości) państwa. W ocenie polityków partii brak jasnych zasad nie ukształtował żadnego ze znanych w świecie modeli ustrojowych, ,ani solidarnościowego państwa społecznej sprawiedliwości, ani katolickiego państwa narodu polskiego, ani silnego państwa porządku, ani liberalnego państwa wolności. Nie jest też, wbrew temu, co głosili jej twórcy i obrońcy, kon-

2 J. Weiler, Chrześcijańska Europa. Konstytucyjny imperializm czy wielokulturowość?, Poznań 2003, s. 30.

3 Zmienione zostały art. 55 oraz 99 Konstytucji RP. Pierwszą nowelizacją z 2006 r. wprowadzono możliwość ekstradycji obywatela polskiego na wniosek innego państwa lub sądowego organu międzynarodowego. Drugą zmianą z 2009 r. rozszerzono przesłanki biernego prawa wyborczego. Ustanowiono, że „wybrana do Sejmu lub do Senatu nie może być osoba skazana prawomocnym wyrokiem na karę pozbawienia wolności za przestępstwo umyślne, ścigane z oskarżenia publicznego”. Strona internetowa Senatu RP, „Zmiany Konstytucji Rzeczypospolitej Polskiej w latach 1997-2011 w świetle projektów ustaw oraz uchwalonych nowelizacji”, <www.senat.gov.pl>, dostęp 5 III 2017.

${ }^{4}$ K.M. Ujazdowski, Reforma Konstytucji albo stabość państwa, „Nasz Dziennik”, 4 IV 2012, nr 80, s. 19. 
stytucją demokratycznego państwa prawa" „, za to pozwolił na ugruntowanie się postkomunizmu kosztem wolnej Rzeczypospolitej. Politycy PiS byli wśród zwolenników zmiany konstytucji i zmodyfikowania obowiązującego systemu rządów. U podstaw krytyki obowiązującej konstytucji legło przekonanie, że „system polityczny jest słaby i należy go gruntownie przebudować" ${ }^{\text {. W }}$ odpowiedzi na pytanie, dlaczego należy zmienić konstytucję, wskazywano na potrzebę powstania IV Rzeczypospolitej, państwa zasadniczo różniącego się od III Rzeczypospolitej, a głęboka zmiana zasad funkcjonowania państwa musiała pociagnąć za sobą uchwalenie nowej ustawy zasadniczej $^{7}$. PiS przygotowało własny projekt konstytucji, który miał eliminować wady Konstytucji RP z 1997 r. $^{8}$

Politycy Prawa i Sprawiedliwości dokonali gruntownej krytyki obowiązującej od 1997 r. ustawy zasadniczej. Zwrócili uwagę na negatywne cechy konstytucji oraz przepisy wpływające na słabość ustrojową państwa. Diagnoza konstytucji zawierała cztery grupy zagadnień: warunki (genezę) uchwalenia obowiązującej od 1997 r. konstytucji, krytykę rozwiązań aksjologicznych i regulacji ustrojowych oraz skutki prawno-ustrojowe przepisów konstytucyjnych.

W ocenie PiS konstytucja RP nie była dziełem przypadku, ale odbiciem konkretnych warunków politycznych i społecznych. Dominowało przekonanie, że w debacie konstytucyjnej lat 1989-1997 partykularne interesy partyjne przeważały nad polską racją stanu, a o kształcie ustawy zasadniczej zadecydował ,zgniły kompromis liberalizmu i socjalizmu”9.W efekcie konstytucja stała się aktem doraźnym, swoistym „,zapisem pierwszego etapu transformacji”. Zarzutem PiS w kwestii warunków uchwalenia ustawy zasadniczej był fakt, że konstytucja została przyjęta przez Sejm II kadencji (1993-1997), który z powodu rozdrobnienia obozu solidarnościowego po wyborach został zdominowany przez partie centrolewicowe. Ponadto podważano reprezentatywność referendum, w którym wzięło udział $43 \%$ obywateli, czyli mniej niż wymagane $50 \%$ (przeciwko konstytucji opowiedziało się $46 \%$ procent głosujących). $\mathrm{Z}$ tego względu polska ustawa zasadnicza nie była uważana za „państwowotwórczą świętość", nie miała mocnego poparcia społecznego i tym samym nie mogła stanowić umocowania ustrojowego i moralnego dla państwa, tylko ,zestaw prawniczych bezpieczników" chroniący postkomunistyczny układ rządzący Polską. Konstytucja była uważana za narzędzie realizacji interesów politycznych i finansowych establishmentu III Rzeczypospolitej ${ }^{10}$.

${ }^{5}$ Strona internetowa Prawa i Sprawiedliwości, <http://pis.org.pl> [dalej: SI PiS], „Konstytucja IV Rzeczypospolitej”, dostęp 22 XI 2016.

${ }^{6}$ Strona internetowa Polskiego Radia, <http://www.polskieradio.pl>, ,Sygnały Dnia z 4 XI 2003 r.,

J. Kaczyński: Płacimy i będziemy płacić, rozm. W. Molak, H. Szrubarz”, dostęp 3 X 2015.

7 SI PiS, „Program PiS”, dostęp 21 XI 2017.

${ }^{8}$ SI PiS, ,„Konstytucja Rzeczpospolitej Polskiej. Projekt Prawa i Sprawiedliwości”, dostęp 21 XI 2017.

${ }^{9}$ K.M. Ujazdowski, Konstytucja, nie rewolucja, „Gazeta Wyborcza”, 25 IV 2005, nr 95, s. 24, 26; J. Sellin, Czas prezydentów, „Rzeczpospolita”, 15 V 2007, nr 112, s. A9.

${ }^{10}$ Strona internetowa portalu Onet.pl, „Remanent Konstytucji. Kaczyński pokazał, gdzie są luki”, $<$ http://wiadomosci.onet.pl>, dostęp 3 VI 2017. 
Drugą grupę zagadnień ocenianych przez PiS stanowiły rozwiązania aksjologiczne. W PiS powszechne było przekonanie, że konstruowanie państwa to także tworzenie jakości moralnej, dlatego aksjologia konstytucji miała być jednoznaczna i zakorzeniona w tradycji. Główny zarzut kierowany do twórców ustawy zasadniczej zawierał się w tezie, że konstytucja w warstwie aksjologicznej pełniła funkcję petryfikatora patologicznego ustroju, mającego wiele cech przeniesionych z systemu komunistycznego. W ocenie PiS w ustawie zasadniczej dominowała niejednoznaczna aksjologia, oparta na laickiej ideologii liberalnej. Świadczył o tym ,rozwlekły, kompromisowy i ogólny" tekst preambuły, w którym zabrakło wskazania na niepodległościowe tradycje, cezury określającej moment przejścia z PRL do niepodległego państwa i mechanizmów zrywających ciagłość z systemem totalitarnym ${ }^{11}$. Politycy PiS mieli zastrzeżenia również do definicji pojęcia ,naród”, która wynikała z przepisów konstytucyjnych. Określenie ,naród” zostało ujęte jako zbiorowość składająca się ze wszystkich obywateli Rzeczypospolitej, a więc także deklarujących inną przynależność narodową, między którymi główna linia podziału biegła wzdłuż osi wierzący-niewierzący. Oceniono, że był to podział anachroniczny, osadzony prawnie jeszcze w PRL, a poczucie przynależności do narodu jako wielopokoleniowej wspólnoty doświadczeń, wartości i celów zastapiono pojęciem ,obywatelskość". Aktywność obywatelska miała być celem samym w sobie, bez odniesień do aksjologii ${ }^{12}$.

Dla PiS potwierdzeniem konstatacji o ułomnościach konstytucji w sferze aksjologicznej były przepisy określające relacje państwo-Kościół i rolę religii w państwie. W przekonaniu polityków partii ,twardy antyklerykalizm, charakterystyczny dla komunistycznej i antykomunistycznej elity, łączył się z chytrym oportunizmem, każącym poszukiwać kompromisu z potężną instytucja"13. PiS za znaczące uchybienie uznawało brak invocatio dei ${ }^{14}$. W ocenie Jarosława Kaczyńskiego, konstytucja powinna zaczynać się wezwaniem „W imię Boga Wszechmogącego”, co miało na celu budowę państwa osadzonego w polskiej tradycji, a nie państwa wyznaniowego. Byłoby to odwołanie do Konstytucji 3 maja oraz konstytucji marcowej, kluczowych ustaw zasadniczych w historii Polski ${ }^{15}$.

W odniesieniu do regulacji ustrojowych głównym zarzutem adresowanym do twórców konstytucji był brak spójnej myśli ustrojowej oraz klarownej wizji trójpodziału władzy i tym samym koncepcji państwa. Dominowało przekonanie, że o ile w 1997 r. de iure istniała idea trójpodziału władzy, o tyle de facto funkcjonował ustrój, w którym każda z władz została zablokowana. Należy podkreślić, że wadli-

${ }^{11}$ SI PiS, „20 przePiSów na Konstytucję”, dostęp 8 I 2018.

12 SI PiS, „Nowoczesna, Solidarna, Bezpieczna Polska. Program Prawa i Sprawiedliwości”, dostęp 8 I 2018.

13 SI PiS, ,Konwencja konstytucyjna Prawa i Sprawiedliwości. Wystapienie prezesa PiS Jarosława Kaczyńskiego", dostęp 23 I 2018.

14 Ibidem.

15 J. Kaczyński, Biznes często to przystań ludzi PRL, rozm. A. Stankiewicz, M. Szułdrzyński, P. Jabłoński, „Rzeczpospolita” 4 IX 2013, nr 206, s. A4-A5. 
wie uregulowany rozdział kompetencji między prezydentem i premierem był najczęściej krytykowanym elementem konstytucji, zarówno przez jej zwolenników, jak i przeciwników ${ }^{16}$.

Diagnoza PiS dotyczyła trzech władz: wykonawczej, ustawodawczej i sądowniczej. Szczególnie wyraźnie krytykowano brak zdecydowania się na jasną regułę ustrojową: system prezydencki, kanclerski lub parlamentarno-gabinetowy. Wskazywano na usankcjonowanie dwugłowej egzekutywy podzielonej między prezydenta i premiera, niejako „zachęconą” do przeszkadzania sobie. Z jednej strony prezydent był wybierany w wyborach powszechnych, cieszył się silnym mandatem zaufania społecznego, z drugiej strony miał okrojone kompetencje w relacjach z Radą Ministrów. Nieograniczone prawo weta zachęcało prezydenta do blokowania działań rządu. Oceniano, że prezydent to „mocarz, gdy chodzi o poparcie społeczne, i karzeł, gdy chodzi o formalnoprawne instrumenty wpływania na polską politykę" ${ }^{\prime 17}$. W odniesieniu do władzy ustawodawczej dowodzono, że polski parlament tylko w niewielkim stopniu wypełniał funkcje kontrolne, a „Senat kopiował prace sejmu”. Należy przy tym podkreślić, że politycy PiS konsekwentnie opowiadali się za istnieniem Senatu, przy znacznym rozszerzeniu jego kompetencji. Hasła dotyczące zniesienia izby wyższej parlamentu, pojawiające się niekiedy ze strony socjaldemokratów, uznawali za „chwytliwy marketing konstytucyjny”. Podkreślali, że Senat ma ponad pięćsetletnią tradycję ustrojową i wielokrotnie przyczynił się do poprawienia jakości prawa tworzonego przez Sejm ${ }^{18}$. Co do oceny judykatywy, to wskazywali przede wszystkim na jej słabość i nieefektywność oraz ulokowanie niejako „poza państwem". Politycy partii nie mieli wątpliwości, że sądownictwo powinno być integralną częścią systemu państwowego przy jednoczesnym zachowaniu zasady podziału i równoważenia się władzy.

Politycy PiS stawiali zarzuty w zakresie „,nowoczesności” i „obywatelskości” konstytucji. Oceniano, że przepisy konstytucyjne nie przystawały do zmian, które zaszły po wstappieniu Polski do Unii Europejskiej, ponieważ po akcesji Polska została pozbawiona nowoczesnego instrumentarium prawnego. W konsekwencji powstał skomplikowany system źródeł prawa, w którym umowy międzynarodowe zyskały pierwszeństwo nad ustawami krajowymi. Niejasny był również zakres kompetencji przekazywanych

${ }^{16}$ Pogląd o braku zdecydowania się na jasną regułę systemu rządów w konstytucji z 1997 r. znalazł odzwierciedlenie w literaturze przedmiotu; vide: R. Chruściak, W. Osiatyński, Tworzenie Konstytucji w Polsce w latach 1989-1997, Warszawa 2001, s. 10; M. Zubik, Glos w dyskusji, [w:] Pięć lat Konstytucji Rzeczypospolitej Polskiej, red. H. Jerzmański, Warszawa 2002, s. 118; M. Lasocki, Projekty zmian Konstytucji z 2 kwietnia 1997 r. na tle rozważań o zmianie konstytucji, „Studia Politologiczne” 2006, t. 10, s. 25-26.

17 Strona internetowa Ryszarda Czarneckiego, ,Potrzebna zmiana konstytucji!”, <http://ryszardczarnecki.blog.onet.pl>, dostęp 12 VIII 2017.

${ }_{18}$ W zakończeniu projektu konstytucji PiS K.M. Ujazdowski napisał: „Wierność pięćsetletniej tradycji ustrojowej zmusza do poszukiwania nowoczesnych form zachowania drugiej izby. Proponujemy Senat jako instytucję oddaloną od bieżącej polityki i z dużą ilością kompetencji dotyczących tworzenia organów państwowych, m.in. NIK i Prezesa Urzędu Pomocy Ofiarom Bezprawia”. SI PiS, „Konstytucja Rzeczypospolitej Polskiej. Projekt Prawa i Sprawiedliwości”, dostęp 23 XI 2017; K.M. Ujazdowski, Reforma Konstytucji..., s. 19; SI PiS, „20 przePiSów na Konstytucję”... 
Unii Europejskiej. Brak „obywatelskości” przejawiał się w istnieniu mechanizmów blokujących inicjatywę referendum obywatelskiego ${ }^{19}$.

Krytyce ze strony polityków PiS podlegały ponadto cztery inne kwestie: 1) rozbudowane przywileje dla zawodów zaufania publicznego, 2) nieprecyzyjność regulacji dotyczących prawa własności, 3) zbyt duża liczba „deklaratywnych i pustych” przepisów traktujących o wolnościach i prawach obywatelskich, która nie szła w parze z jakością stanowionego w tej kwestii prawa oraz 4) „,niekontrolowany” proces wnoszenia poprawek do ustaw, który - w ocenie PiS — dawał możliwość psucia prawa ${ }^{20}$.

Nie bez oceny PiS pozostawały skutki prawno-ustrojowe konstytucji z 1997 r. Wskazywano na szkodliwość przepisów konstytucyjnych, skutkującą utrwaleniem postkomunizmu i tym samym, zablokowaniem funkcjonowania demokratycznego państwa prawa. Konstytucja utrwalała nieufność obywateli do państwa, a prawo odgrywało rolę instrumentu w rękach silnych grup i jednostek ${ }^{21}$. W PiS dominowało przekonanie, że w konstrukcję ustrojową III RP został wpisany — choć niezadeklarowany wprost — „imposybilizm”. W rozumieniu polityków partii oznaczał on programową niemożność podejmowania przez państwo działań koniecznych w kontekście ochrony jego interesów i dobra obywateli. Praktycznymi przejawami ,imposybilizmu” były co najmniej trzy zjawiska: ograniczenie możliwości legalnego zwalczania różnego rodzaju patologii; działanie organów państwa w interesie anonimowych i pozaprawnych ośrodków dyspozycyjnych, realizowanych poza demokratyczną kontrolą; niezdolność państwa do mobilizowania sił i środków w celu rozwiązywania problemów zbiorowych, takich jak problemy mieszkaniowe, infrastrukturalne czy związane z bezpieczeństwem obywateli.

W sensie ideologicznym i ustrojowym „imposybilizm” przejawiał się w swoistym rozumieniu idei państwa prawa, w tym zasady ochrony praw nabytych, skomplikowaniu procesu legislacji na szczeblu centralnym, co doprowadziło do rozmycia odpowiedzialności za treść przepisów i de facto poddało je wpływom lobbystycznym. W ocenie PiS sprzyjała temu ,nadaktywność” Trybunału Konstytucyjnego, który na podstawie interpretacji konstytucji gwarantował nienaruszalność postkomunistycznego status quo, korporacjonizm definiowany jako formalna lub nieformalna władza korporacji zawodowych oraz akceptowanie przez elity polityczne naruszania jednej z zasad państwa prawa, czyli monopolu państwa w stosowaniu środków przymusu. Wszystkie te „patologiczne" regulacje i swoista filozofia państwa uniemożliwiały sprawowanie przez państwo kontroli nad działającymi w sposób niejawny jednostkami i grupami.

19 Przepisy konstytucyjne skonstruowane są tak, aby większość rządowa mogła w każdej chwili zablokować zarządzenie referendum. W 2012 r. Sejm odrzucił wniosek 2 mln obywateli w sprawie referendum odnoszącego się do wieku emerytalnego.

20 SI PiS, ,20 przePiSów na konstytucję”...; strona internetowa Sejmu RP, <www.sejm.gov.pl $>$ [dalej SI Sejmu RP, wypowiedź Przemysława Gosiewskiego z 1 IV 2009 r. w debacie po sprawozdaniu Komisji Nadzwyczajnej o poselskim projekcie ustawy o zmianie Konstytucji Rzeczypospolitej Polskiej”, dostęp 23 I 2018.

21 SI PiS, „20 przePiSów na Konstytucję”...; SI PiS, „Konwencja konstytucyjna Prawa i Sprawiedliwości. Wystapienie prezesa PiS Jarosława Kaczyńskiego”, dostęp 23 I 2018. 
W myśli politycznej PiS dominowało przekonanie, że część elit politycznych była przeciwna zbudowaniu silnego państwa. Oceniano, że cechowała ją mentalność antypaństwowa sięgająca korzeniami PRL. Mimo upadku komunistycznej dyktatury niechęć do państwa pozostała, a postulaty zmierzające do ograniczenia władzy państwowej, które w PRL mogły być spełnione w niewielkim zakresie, zostały zrealizowane po 1989 r. Skutkiem było ograniczenie działania demokratycznego państwa w interesie obywateli. Elita polityczna poprzez swoją działalność podważała sens wartości demokratycznych, takich jak równość wszystkich obywateli wobec prawa i obowiązek jego przestrzegania oraz szacunek wobec państwa.

Należy podkreślić, że dla PiS silne państwo było niezbędne do utrzymania porządku, który warunkował ochronę wolności. Przestrzegano przed rozumieniem siły państwa jako wszechwładzy instytucji politycznych, realizacji interesów państwa kosztem społeczeństwa oraz jego nadmiernej ingerencji w gospodarkę i codzienne życie obywateli ${ }^{22}$.

\section{ZASADY UCHWALANIA USTAWY ZASADNICZEJ}

Idea „dobrej konstytucji” w myśli politycznej PiS wyrażała „wolę budowy silnego i podmiotowego państwa, które pełniłoby rolę depozytariusza wartości i dziedzictwa historycznego"23. Konsekwencją takiego sposobu myślenia było przekonanie o konieczności zachowania rozwagi i kierowania się określonymi regułami przy jej uchwalaniu. Politycy PiS wskazywali, że spełnienie warunków wstępnych zagwarantuje stabilny lad prawny.

W myśli politycznej PiS występowało co najmniej osiem zasad, będących warunkiem sine qua non przygotowania „,dobrej” ustawy zasadniczej. Pierwszą była zasada „pozytywnego konstruktywizmu”, która miała zagwarantować mocne osadzenie planowanego porządku ustrojowego w systemie wartości. Chodziło też o zdolność do wyjścia poza istniejący układ interesów i instytucji z nimi związanych. Realizację zasady uznawano za szczególnie trudna, ponieważ wymagała określenia wizji porządku, który realnie da się wprowadzić w życie, chociaż jest kompromisem między tym, co oczekiwane, pożąane i tym, co możliwe.

Drugą zasadą był „empiryzm”, który zakładał konfrontowanie idei, koncepcji i projektów instytucji państwowych z praktyką państwową II i III Rzeczypospolitej oraz doświadczeniem innych państw demokratycznych. Na ich tle można określić z dostateczną dozą pewności, jak naprawdę będą funkcjonować poszczególne instytucje, jak będą się układać zależności między nimi. Konieczna była też szczegółowa wiedza na temat funkcjonowania instytucji innych państw demokratycznych.

22 SI PiS, „Nowoczesna, Solidarna, Bezpieczna Polska. Program Prawa i Sprawiedliwości”, dostęp 8 I 2018; J. Kaczyński, Liczę na lawinę, rozm. C. Bielakowski, D. Zdort, „Rzeczpospolita” z 11 III 2003 r. nr 59, s. A6; Jaka prezydentura? Debata z udziałem R. Matyi, R. Bugaja i L. Dorna, rozm. M. Szułdrzyński, „Nowe Państwo” 2007, nr 1, s. 13.

${ }^{23}$ K.M. Ujazdowski, Reforma Konstytucji..., s. 19. 
Zasada „realizmu aksjologicznego” wynikała z przeświadczenia, że nie ma konstytucji neutralnych aksjologicznie. Reguła pozwalała dokonać wyboru spośród „,konkurencyjnych” systemów wartości i „osadzić w nim konstytucję, bez naruszania równości praw tych, którzy moralnych poglądów większości nie podzielali. Nienaruszanie równości praw nie oznaczała jednak uznania roszczeń, by poglądy mniejszości były stawiane na pierwszym miejscu i by nie podlegały ocenie $\mathrm{i}$ - co za tym idzie - selekcji. Wskazywano na istnienie w Polsce jednego powszechnie znanego i funkcjonującego w skali masowej systemu wartości, opierającego się na nauce Kościoła katolickiego i tradycji narodowej. Przeciwstawiano mu nihilizm, a ponieważ konstytucja nie mogła wyrażać tendencji nihilistycznych, to w sferze aksjologicznej nie było dla PiS wyboru, a wszelkie próby skonstruowania kompromisu między tradycyjnym systemem wartości a nihilizmem nie miały sensu. Analiza świadectw myśli politycznej PiS pozwala wnioskować, że związek między etyką i prawem był dla polityków partii oczywisty. Opowiadano się za moralizmem prawnym, zakładającym, że prawo powinno preferować określony system wartości ${ }^{24}$. Normy moralne, przekształcane w przepisy prawne, wpływały zasadniczo na proces funkcjonowania państwa i sprawowania władzy. W literaturze politologicznej i socjologicznej powszechny był pogląd, że prawo potrzebowało oparcia w moralności, aby miało społeczny szacunek i akceptację. Mogło być stosowane tylko wtedy, kiedy odzwierciedlało wartości społeczne i moralne. Warto podkreślić, że wartości moralne i społeczne (demokracja, godność osoby ludzkiej, sprawiedliwość, własność prywatna, życie) najczęściej były ujęte $\mathrm{w}$ reguly prawne ${ }^{25}$.

Zasadą czwartą był „realizm społeczny i polityczny”, który umożliwiał ocenę dorobku II i III Rzeczypospolitej oraz PRL i na jej podstawie określenie tożsamości nowego państwa. Tworzenia konstytucji nie można było abstrahować od pytań, jakie niósł moment historyczny, czy to w odniesieniu do spraw związanych ze stosunkiem do PRL (kontynuacja lub dyskontynuacja), a także II Rzeczypospolitej i III Rzeczypospolitej, czy też do kwestii własnościowych (w tym sprawy roszczeń wobec Polski), korupcji i - szerszej - rozkładu państwa, bezrobocia, patologii społecznych etc., i wreszcie ważnych spraw związanych z przynależnością do Unii Europejskiej.

Piątą zasadą było ,zachowanie równowagi praw i wolności obywatelskich oraz obowiązków wobec państwa”. Sprowadzała się do osiagnięcia stanu, w którym prawa i wolności obywatelskie, gwarantujące swobodę obywatelom i chroniące ich przed opresją ze strony państwa, nie paraliżowały działań tego państwa.

${ }^{24}$ SI Sejmu RP, „,Wypowiedź Jarosława Kaczyńskiego z 18 IX 2003 r. w debacie nad projektem uchwały Sejmu Rzeczypospolitej Polskiej deklarującej intencję ratyfikacji nowego traktatu regulującego zasady i ustrój Unii Europejskiej”, dostęp 21 XI 2017.

${ }^{25} \mathrm{~W}$. Lang, Aksjologia polskiego systemu prawa w okresie transformacji ustrojowej, [w:] Zmiany spoteczne a zmiany w prawie. Aksjologia, konstytucja, integracja europejska, red. L. Leszczyński, Lublin 1999, s. 47 i n.; A. Bator, K. Kucharski, Wartości absolutne a pojęcie praworzqdności, [w:] Demokratyczne państwo prawne. Aksjologia, struktura, funkcje. Studia i szkice, red. H. Rot, Wrocław 1994, s. 85 i n.; W. Lang, Zwiqzki między prawem i moralnościa w procesie tworzenia prawa, [w:] Prawo w zmieniajacym się spoteczeństwie. Księga pamiqutkowa z okazji 70-lecia urodzin Profesor Marii Boruckiej-Arctowej, red. G. Skapska, Toruń 2000, passim. 
Szósta zasada „niesprzeczności uprawnień obywateli z prawami ekonomii” oznaczała, że konstytucja nie powinna tworzyć praw socjalnych, które utrudniają lub uniemożliwiają rozwój ekonomiczny państwa. Przestrzegano jednocześnie, że zasada ta nie oznaczała liberalnego postulatu ograniczenia uprawnień socjalnych, ale miała zapobiec tworzeniu praw, które blokowałyby państwa ${ }^{26}$.

Zasada siódma, czyli ,unikania konfliktów”, opierała się na założeniu, że konstytucja nie powinna być źródłem konfliktów, które mogłyby się rodzić na tle jej przepisów, np. poprzez usankcjonowanie ,iluzji socjalnych”, czyli rozbudowę praw socjalnych, z których wynikałyby niemożliwe do zaspokojenia roszczenia ${ }^{27}$.

Ostatnią, choć nie mniej ważną zasadą była „przejrzystość przepisów konstytucji”. Sformułowania ustawy zasadniczej miały być jasne i szczegółowo dopracowane. Miała to być odpowiedź na brak powszechnie obowiązujących kryteriów i reguł życia społecznego III RP. Konsekwencją takiej oceny był postulat, że przepisy konstytucyjne muszą być precyzyjne ,nawet wtedy, jeśli wymaga to odejścia od powszechnie stosowanego języka prawniczego" ${ }^{\text {. }}$.

Wymienione zasady miały dla PiS charakter elementarny. Bez ich przestrzegania nie było możliwe stworzenie nie tylko dobrej, ale nawet „dostatecznej” konstytucji ${ }^{29}$.

W myśli politycznej PiS występowało rozróżnienie na dwa rodzaje konstytucji: deskryptywną i konstruktywistyczną. Konstytucję deskryptywną (opisowa) rozumiano jako ujęcie w formuły prawne istniejącego stanu życia publicznego i społecznego, niemające zasadniczego znaczenia dla sprawnego funkcjonowania państwa. Konstytucja taka ograniczała się do opisu reguł, według których miała być sprawowana władza w państwie.

W odróżnieniu od deskryptywnej, konstytucja konstruktywistyczna miała pełnić funkcję ,narodowotwórczą” i ,państwowotwórczą”, poprzez umocowanie prawne zasad życia publicznego i społeczno-gospodarczego. W PiS od początku istnienia partii dominowało przekonanie o nieodzowności opracowania konstruktywistycznej formuły polskiej ustawy zasadniczej, w której wyrażano by wolę daleko idących zmian. Podkreślano, że Polska w 1989 r. wyszła z trwającego pół wieku zniewolenia i totalitaryzmu i zaistniały wszelkie przesłanki do tego, aby zabiegać o nowe państwo z klarownie określonymi zasadami porządku państwowego, społecznego i gospodarczego.

Wydaje się, że podział ten odpowiadał występującemu w literaturze przedmiotu rozróżnieniu na konstytucję proceduralną (deskryptywna) i normatywną (preskryptywna). Pierwsza określała prawne i polityczne ramy instytucji publicznych oraz granice władzy politycznej w celu ochrony procesów demokratycznych i podstawowych praw człowieka. Znajdowała zastosowanie w państwach, w których nie było zgody co do wartości lub tożsamości. Jej celem było ustalenie konsensu społecznego w sprawie

${ }^{26}$ SI PiS, ,,Konwencja konstytucyjna Prawa i Sprawiedliwości. Wystapienie prezesa PiS Jarosława Kaczyńskiego", dostęp 23 I 2018.

${ }^{27}$ Ibidem.

${ }^{28}$ Ibidem.

29 SI PiS, „Program PiS”, dostęp 21 XI 2017. 
stosowania demokratycznych procedur w celu rozwiązania występujących w społeczeństwie różnic. Konstytucje proceduralne były pozbawione warstwy aksjologicznej składającej się na wizję dobrego społeczeństwa lub narodu, podstawowych zasad filozoficznych lub ideologicznych, ale opierały się jedynie na minimalnym zobowiązaniu do wspólnej egzystencji w granicach państwa, rozwiązywaniu problemów za pośrednictwem instytucji politycznych i szanowaniu praw człowieka. Konstytucja normatywna pełniła funkcję ,podstawowej karty tożsamości państwa” i odgrywała kluczową rolę w definiowaniu wspólnych celów i wartości, leżących u podstaw państwa. Normatywny model konstytucji był szczególnie pożądany w państwach, w których istniała potrzeba ponownego proklamowania zasad ustrojowych, np. w państwach postkomunistycznych. Większość współczesnych konstytucji zawiera — w różnym stopniu - cechy obu modeli konstytucji ${ }^{30}$.

Podobnego rozróżnienia dokonała Hanna Lerner. Wskazała na dwa paradygmaty reprezentujące dwa odrębne typy tożsamości i przejawiające dwa różne sposoby rozumienia relacji między konstytucją a obywatelami. Pierwsza to konstytucja esencjalistyczna lub konstytucja państwa narodowego, która odzwierciedlała wizję wspólnoty narodowej, chroniąc wartości o znaczeniu narodowym, w tym np. język narodowy i religię. Drugi paradygmat znalazł odzwierciedlenie w liberalnych konstytucjach, które wyrażały wspólną tożsamość obywatelską członków społeczeństwa poprzez sformalizowanie podstawowych zasad demokratycznego uczestnictwa, reprezentacji i deliberacji ${ }^{31}$. Pierwszy model konstytucji konstruował ethnos (wspólnotę narodowa), drugi - demos (wspólnotę obywatelska).

Politycy PiS opowiadali się za ustawą zasadniczą państwa narodowego, która z jednej strony powinna odegrać rolę „,narodowotwórczą”, jasno określając źródła tożsamości narodowej, z drugiej zaś strony — „państwowotwórczą”, wprowadzając zasady ustrojowe i społeczne. Podkreślano przy tym ważkość kontekstu historycznego i wyzwań. W XXI w. niewątpliwie takimi wyzwaniami były: kryzys demokracji, wyzwania związane z integracją europejską i globalizacją, trendy obyczajowe etc.

„Narodotwórcza” rola konstytucji w myśli politycznej PiS oznaczała wzmocnienie tożsamości poprzez jej dokładne sprecyzowanie oraz nadanie jej mocy integracyjnej i mobilizacyjnej. Oznaczałoby to umocowanie wspólnoty Polaków na silnej tożsamości narodowej. Forsowane przez środowiska liberalne i lewicowe wzorce Polaka-obywatela, Polaka-Europejczyka i Polaka-człowieka wolnego od ograniczeń, szczególnie w sferze obyczajowej, były w przekonaniu polityków PiS fikcyjne i destrukcyjne dla narodu.

Tożsamość była dla PiS ważną właściwością, pozwalającą narodowi i państwu trwać w zmiennych warunkach wewnętrznych i zewnętrznych. Wspólnota polityczna mogła powstać tylko na fundamencie czytelnie zdefiniowanej tożsamości. Tożsamość narodowa była warunkiem koniecznym egzystencji państwa, a jej obrona przed anihi-

${ }^{30}$ A. Rathore, N. Hinduja, Analysis of Indian Constitution, ,International Journal of Research and Analysis" 2016, t. 4, s. 11.

31 H. Lerner, Making Constitutions in Deeply Divided Societies, Cambridge 2011, s. 25-26. 
lacją i wzmacnianie stanowiły nadrzędny cel państwa, wynikający wprost z racji sta$\mathrm{nu}^{32}$. PiS wskazywało na trzy filary polskiej tożsamości narodowej: 1) chrześcijański (wartości chrześcijańskie); 2) historyczno-patriotyczny (demokratyczna tradycja wielokulturowej I Rzeczypospolitej i polskich walk o niepodległość) oraz 3) antytotalitarny (tradycja polskiego sprzeciwu wobec nazizmu i komunizmu, $w$ tym doświadczenia „Sierpnia '80”) ${ }^{33}$.

Naród — podmiot tożsamości — traktowano jako wspólnotę kultury, języka, doświadczenia historycznego, tradycji politycznej i wartości cywilizacyjnych, przeżywanego losu, najszerszą grupę społeczną stanowiącą efektywną podstawę dla demokratycznych wspólnot politycznych. Przestrzegano przed definiowaniem narodu w sensie etnicznym z uwagi na fakt, że naród polski kształtował się poprzez łączenie we wspólnotę ludzi o różnej przynależności etnicznej. Afirmacja polskiej wspólnoty narodowej łączyła się nierozerwalnie $\mathrm{z}$ akceptacją podmiotowości innych narodów. Przynależność do narodu polskiego traktowano jako wartość z dwóch powodów. Pierwszym był pogląd o esencjonalistycznym pochodzeniu wspólnoty narodowej, czyli poprzez urodzenie i wychowanie w kulturowym dziedzictwie przodków. Drugi argument wiązał się z dumą narodową z cech polskiej tradycji, połączonej trwale $\mathrm{z}$ chrześcijaństwem $\mathrm{i}$ jednocześnie umocowanej w wolności i równości ${ }^{34}$. Za niezwykle niebezpieczną tendencję uważano zastępowanie pojęcia „,naród” terminem „społeczeństwo", uważanie siebie za Europejczyka, a nie Polaka. Wielokrotnie podkreślano, że „naród bez pamięci i tożsamości przestaje być narodem, staje się grupa etniczną". Aby temu zapobiec, postulowano, aby tożsamość narodową młodego pokolenia budować na podstawie jego emocjonalnego związku z własną gminą, regionem i ojczyzną ${ }^{35}$.

W tym kontekście odwoływano się do umowy społecznej jako rozwiązania mającego głębokie zakorzenienie tak w europejskiej tradycji intelektualnej i politycznej, jak i w polskiej tradycji. Najefektywniejszym sposobem stworzenia konstytucji, która mogłaby odegrać rolę „,narodowotwórczą”, było doprowadzenie do zawarcia umowy społecznej między tymi siłami społecznymi, które dostrzegały konieczność zmian i jednocześnie prezentowały postawę patriotyczną afirmującą naród i suwerenność państwowa. Umowa społeczna oznaczałaby budowę pozytywnego kontekstu społecznego, świadomość „wielkiej zmiany” i poczucie uczestnictwa, co pozwoliłoby na zrównoważenie interesów uczestniczących w życiu publicznym elit oraz wielu grup społecznych. Wskazywano przy tym na fakt, że naród jako wspólnota ukształtowana

32 SI PiS, „Myśląc Polska. Konwencja Programowa Prawa i Sprawiedliwości oraz zjednoczonej prawicy Katowice 3-5 lipca 2015 r.”, dostęp 4 V 2017.

${ }^{33}$ SI PiS, „Prawo i Sprawiedliwość. Program 2005. IV Rzeczpospolita — Sprawiedliwość dla Wszystkich”, dostęp 4 VI 2017; SI PiS, „Nowoczesna, Solidarna, Bezpieczna Polska. Program Prawa i Sprawiedliwości”, dostęp 4 VI 2017; SI PiS, „Zdrowie. Praca. Rodzina. Program Prawa i Sprawiedliwości 2012”, dostęp 22 I 2018.

${ }^{34}$ Ibidem.

${ }^{35}$ SI Sejmu RP, „Oświadczenie posła PiS Bogdana Rzońcy z 15 III 2012 r.”, dostęp 12 V 2017; SI Sejmu RP, „Przemysław Gosiewski: interpelacja nr 6941 do prezesa Rady Ministrów w sprawie wycofania się rządu PO i PSL z programu finansowania wycieczek patriotycznych z 1 XII 2008 r.”, dostęp 4 VI 2017. 
historycznie, o charakterze międzypokoleniowym, nie był tworem umowy. Porozumienie społeczne było traktowane jako metoda przełamania kryzysu i miało służyć dowartościowaniu go $^{36}$.

W odniesieniu do roli „państwowotwórczej” określono zespół zasad prakseologicznych, będących swoistymi drogowskazami nowego kształtu ustrojowego państwa: 1) usankcjonowanie jednego, dominującego ośrodka władzy wykonawczej i klarowne zdefiniowanie systemu rządów; 2) niedopuszczenie do autonomizacji części aparatu państwowego (wojska, służb specjalnych, administracji, wojewodów etc.); 3) uznanie realnych prerogatyw instytucji państwowych, w szczególności uprawnień kontrolnych; 4) zakaz obciążania sądownictwa obowiązkami ponad możliwości, w tym obowiązkiem podejmowania decyzji politycznych i ekonomicznych w skali państwa; 5) umocowanie instytucji kontrolnych poza systemem władzy w celu ich ochrony przed uwikłaniem w bieżące spory polityczne; 6) apolityczność sędziów; 7) zapewnienie pluralizmu i zasady politycznej równości przy powoływaniu instytucji państwowych; 8) ,zakaz mieszania administracji rządowej z samorządowa, samorządu z autonomia, a autonomii z federalizmem"; 9) precyzyjne sformułowanie przepisów dotyczących stanów nadzwyczajnych; 10) zakaz traktowania praw urzędników jak praw obywatelskich oraz 11) zlikwidowanie sfer administracji władzy pozostających poza kontrolą państwa ${ }^{37}$.

\section{WNIOSKI KOŃCOWE}

Na ukształtowanie się myśli politycznej Prawa i Sprawiedliwości niewątpliwie wpłynęła diagnoza ustroju III Rzeczypospolitej, ugruntowanego przepisami konstytucyjnymi z 1997 r. PiS, kwestionując znaczną część dorobku ustrojowego Polski po 1989 r., widział potrzebę gruntownych zmian niemal we wszystkich dziedzinach życia politycznego i społecznego. Odpowiedzią partii na wielopłaszczyznowy kryzys państwa był projekt IV Rzeczypospolitej, oznaczający zasadniczą przebudowę państwa. Punktem wyjścia do proponowanych zmian miała być nowa konstytucja.

Analiza poglądów polityków PiS odnoszących się do Konstytucji RP z 1997 r. prowadziła do pięciu wniosków.

Po pierwsze, polską ustawę zasadniczą uważano za efekt „zgniłego” kompromisu między lewicą postkomunistyczną a Unią Wolności. Oceniono, że obie siły polityczne były — choć z różnych powodów — zainteresowane konserwowaniem postkomunistycznego status quo, stworzeniem systemu instytucji, których zadaniem było utrwalenie tego stanu i blokowanie prób jego zmiany.

Po drugie, przepisy Konstytucji RP z 1997 r. utrwalały postkomunizm wraz z wszystkimi jego patologiami, godzaccymi w potencjał polityczny państwa, rozumiany jako efektywność rządzenia, zdolność władzy publicznej do podejmowania decyzji i wcielania ich w życie.

\footnotetext{
${ }^{36}$ SI PiS, „Program PiS”, dostęp 18 XII 2017.

37 Ibidem.
} 
Po trzecie, w ocenie polityków PiS przepisy polskiej konstytucji wyrastały z okresu PRL, były obciążone różnorakimi ustępstwami i kompromisami, dlatego nie mogły zbudować stabilnego systemu prawnego, którego podstawę stanowiłaby moralność chrześcijańska. Ustawę zasadniczą z 1997 r. nazywano konstytucją słabego państwa.

Po czwarte, aby dokonać zmiany ustawy zasadniczej, szczególnie dwa argumenty uznano za wystarczające. Jedna kwestia wiązała się z przekonaniem, że wiele praw zapisanych w konstytucji miało charakter czysto teoretyczny, ponieważ słabe państwo nie mogło wprowadzić wielu zasad w życie. Ponadto wskazywano na „niechlubną” praktykę władz III RP, polegającą na wykorzystywaniu niejasnych kompetencji najwyższych organów konstytucyjnych do walki politycznej i wywoływania sporów.

Po piąte, zastosowanie zasad uchwalenia „dobrej konstytucji” uważano za warunek sine qua non nie tylko „ustrojotwórczego”, ale również „państwowotwórczego” i ,narodotwórczego" charakteru konstytucji. Dobra, konstruktywistyczna ,ustawa zasadnicza" państwa narodowego miała bowiem preferować system wartości, określać tożsamość historyczną polskiego narodu oraz formułować reguły tworzenia i interpretowania prawa.

Poglądy PiS na konstytucję III RP wpisywały się w szerszy projekt budowy silnego państwa. Dominował pogląd, że „demokratyczne” czy „liberalne” wartości nie były w stanie określić podstaw ideowych ładu społecznego i politycznego. Za priorytet uznano klarowne zdefiniowanie tożsamości antykomunistycznej i oparcie modernizacji państwa na tradycji. Uważano, że mocne fundamenty moralne, mające źródło w chrześcijaństwie podniosą autorytet państwa. Dominującą rolę w przestrzeni publicznej miała pełnić moralność chrześcijańska i nauka społeczna Kościoła katolickiego, a ich prawnym umocowaniem miały być przepisy konstytucyjne.

BIBLIOGRAFIA

ŹRÓDŁA INTERNETOWE

Strona internetowa Polskiego Radia, <http://www.polskieradio.pl>, „Sygnały Dnia z 4 XI 2003 r., J. Kaczyński, Ptacimy i będziemy płacić, rozm. W. Molak, H. Szrubarz”.

Strona internetowa portalu Onet.pl, $<$ http://wiadomosci.onet.pl $>$, „,Remanent Konstytucji. Kaczyński pokazał, gdzie są luki” z 31 III 2017 r.

Strona internetowa Prawa i Sprawiedliwości, $<$ http://pis.org.pl $>$ :

„20 przePiSów na Konstytucję”.

„Konstytucja IV Rzeczypospolitej”.

„Konstytucja Rzeczypospolitej Polskiej. Projekt Prawa i Sprawiedliwości”.

„Konwencja konstytucyjna Prawa i Sprawiedliwości. Wystapienie prezesa PiS Jarosława Kaczyńskiego".

„Myśląc Polska. Konwencja Programowa Prawa i Sprawiedliwości oraz zjednoczonej prawicy Katowice 3-5 Lipca 2015 r.”.

„Nowoczesna, Solidarna, Bezpieczna Polska. Program Prawa i Sprawiedliwości”.

„Prawo i Sprawiedliwość. Program 2005. IV Rzeczpospolita — Sprawiedliwość dla Wszystkich". 
„Program PiS”.

„Zdrowie. Praca. Rodzina. Program Prawa i Sprawiedliwości 2012”.

Strona internetowa Sejmu Rzeczypospolitej Polskiej, <www.sejm.gov.pl>:

„Oświadczenie posła PiS Bogdana Rzońcy z 15 III 2012 r.”

„Przemysław Gosiewski: interpelacja nr 6941 do prezesa Rady Ministrów w sprawie wycofania się rządu PO i PSL z programu finansowania wycieczek patriotycznych z 1 XII 2008 r.".

„Wypowiedź Jarosława Kaczyńskiego z 18 IX 2003 r. w debacie nad projektem uchwały Sejmu Rzeczypospolitej Polskiej deklarującej intencję ratyfikacji nowego traktatu regulującego zasady i ustrój Unii Europejskiej”.

„Wypowiedź Przemysława Gosiewskiego z 1 IV 2009 w debacie po sprawozdaniu Komisji Nadzwyczajnej o poselskim projekcie ustawy o zmianie Konstytucji Rzeczypospolitej Polskiej".

Strona internetowa Senatu RP, <www.senat.gov.pl>, „Zmiany Konstytucji Rzeczypospolitej Polskiej w latach 1997-2011 w świetle projektów ustaw oraz uchwalonych nowelizacji”.

\section{PIŚMIENNICTWO}

Chruściak R., Osiatyński W., Tworzenie Konstytucji w Polsce w latach 1989-1997, Instytut Spraw Publicznych, Warszawa 2001.

Constitutional Mythologies. New Perspectives on Controlling the State, red. A. Marciano, Springer, Nowy Jork 2011, https://doi.org/10.1007/978-1-4419-6784-8.

Demokratyczne państwo prawne. Aksjologia, struktura, funkcje. Studia i szkice, red. H. Rot, Wydawnictwo Uniwersytetu Wrocławskiego, Wrocław 1994.

Lasocki M, Projekty zmian Konstytucji z 2 kwietnia 1997 r. na tle rozważań o zmianie konstytucji, ,Studia Politologiczne” 2006, t. 10.

Lerner H., Making Constitutions in Deeply Divided Societies, Cambridge University Press, Cambridge 2011, https://doi.org/10.1017/cbo9780511793394.

Pięć lat Konstytucji Rzeczypospolitej Polskiej, red. H. Jerzmański, Wydawnictwo Sejmowe, Warszawa 2002.

Prawo w zmieniajacym się społeczeństwie. Księga pamiatkowa z okazji 70-lecia urodzin Profesor Marii Boruckiej-Arctowej, red. G. Skapska, Wydawnictwo Adam Marszałek, Toruń 2000.

Rathore A., Hinduja N., Analysis of Indian Constitution, „International Journal of Research and Analysis" 2016, t. 4.

Weiler J., Chrześcijańska Europa. Konstytucyjny imperializm czy wielokulturowość?, przekł. W. Michera, Wydawnictwo w drodze, Poznań 2003.

Zmiany spoleczne a zmiany $w$ prawie. Aksjologia, konstytucja, integracja europejska, red. L. Leszczyński, Wydawnictwo UMCS, Lublin 1999. 